\title{
Pemanfaatan Metode Differential Intermerometry Synthetic Aperture Radar (DInSAR) untuk Pemantauan Deformasi Akibat Aktivitas Eksploitasi Panasbumi
}

\author{
Roni Kurniawan dan Ira Mutiara Anjasmara \\ Jurusan Teknik Geomatika, Fakultas Teknik Sipil dan Perencanaan, Institut Teknologi Sepuluh Nopember (ITS) \\ Jl. Arief Rahman Hakim, Surabaya 60111 Indonesia \\ e-mail:ira@geodesy.its.ac.id
}

\begin{abstract}
Abstrak- Indonesia merupakan negara yang mempunyai kondisi geologis yang unik karena berada pada pertemuan 3 lempeng tektonik besar, yaitu Lempeng Indo-Australia, Lempeng Eurasia dan Lempeng Pasifik. Indonesia juga berada pada zona "Cincin Api Pasifik", yaitu daerah barisan gunung api vulkanik yang aktif. Wilayah Indonesia yang berada di daerah cincin api pasifik tersebut membawa manfaat yang sangat besar. Salah satu manfaatnya adalah potensi energi panasbumi. Area Lahendong merupakan lapangan panas bumi pertama dan satusatunya di Sulawesi. Cadangan terbukti reservoir Lahendong adalah sebesar $80 \mathrm{MW}$ dengan potensi pengembangan sebesar 150 MW. Area Lahendong mempunyai karakteristik reservoir low permeability namun memiliki temperatur sangat tinggi. Seperti energi-energi lainnya, energi panasbumi juga memiliki kelebihan dan kekurangan yang jamak, karena tidak ada energi yang benar-benar sempurna dampak kebermanfaatnya. Salah satu dampak negatif yang dapat terjadi adalah terjadinya deformasi yang disebabkan oleh ekspl oitasi fluida panasbumi itu sendiri. Penelitian ini bertujuan untuk memantau aktivitas dari eksploitasi panasbumi di PLTP Lahendong, Sulawesi Utara dengan metode Differential Interferometric Synthetic Aperture Radar (DInSAR). Sedangkan untuk pengolahannya menggunakan perangkat lunak bebas terbuka (open source software) GMTSAR untuk mengolah data satelit ALOS-PALSAR daerah eksploitasi panasbumi Lahendong. Metode yang digunakan adalah dengan melakukan proses pemfokusan data $S A R$, transformasi koordinat ke sistem radar menggunakan infromasi orbit yang teliti, image alignment, interferome dan phase unwrapping menggunakan algoritma SNAPHU. Hasil metode DInSAR mengindikasikan bahwa telah terjadi proses deformasi di sekitar unit 1 dan 2 area eksploitasi panasbumi Lahendong berupa penurunan muka tanah sebesar 3 sampai 4 cm..
\end{abstract}

Kata Kunci-ALOS PALSAR, DInSAR, Eksploitasi Panasbumi, GMTSAR, Line of Sight

\section{PENDAHULUAN}

$\mathrm{S}$ AMPAI saat ini, Indonesia diketahui memiliki ketersediaan potensi energi geothermal yang sangat melimpah, yaitu sekitar $40 \%$ dari cadangan energi geothermal di seluruh dunia [1]. Terdapat 265 titik lokasi prospek geothermal yang tersebar di sepanjang jalur vulkanik yang membentang dari Pulau Sumatera, Jawa, Bali, Nusa Tenggara, Sulawesi, Maluku, dan Papua. PLTP Lahendong salah satunya, merupakan lapangan panas bumi pertama dan satu-satunya di Sulawesi. Berdasarkan data tahun 2010, total pembangkitan PLTP Lahendong sebesar $60 \mathrm{MW}$ (3 x 20MW) dapat menyumbang hingga $40 \%$ kebutuhan listrik di Sulawesi Utara [2]. Seiring dengan perkembangan teknologi yang sangat pesat, saat ini telah memunculkan berbagai metode untuk melakukan pemantauan terhadap aktifitas deformasi. InSAR (Interferometric Synthetic Aperture Radar) merupakan salah satu teknik yang mampu digunakan untuk mengidentifikasi terjadinya deformasi di permukaan tanah dengan memanfaatkan data dari satelit penginderaan jauh aktif yaitu RADAR (Radio Detectionand Ranging). Pada teknik ini dilakukan pembentukan interferogram yang didapat dari dua buah atau lebih citra SAR (master dan slave) yang direkam pada objek yang sama di permukaan bumi namun pada waktu yang berbeda. Jika suatu titik di tanah begerak, maka jarak antara sensor dengan titik akan berubah, dan berpengaruh pada nilai phase yang direkam oleh sensor SAR. Nilai beda phase inilah yang menunjukkan adanya ground movement. Interferogram yang terbentuk memiliki efek topografi dan atmosferik, oleh karena itu perlu dilakukan pengurangan dengan proses differential inferometry SAR (DInSAR), sehingga dihasilkan informasi deformasi serta dapat diketahui besar pergerakan tanah (subsidance atau uplift) yang terjadi.

Data yang digunakan dalam penelitian ini adalah data PALSAR (Phased Array type L band Synthetic Aperture Radar). PALSAR merupakan salah satu sensor aktif dengan sistem SAR yang dibawa oleh satelit ALOS (Advanced Land Observing Satellite). Sensor yang membawa saluran L dengan panjang gelombang $23,6 \mathrm{~cm}$ ini dapat digunakan pada siang maupun malam hari [3].

Dengan menerapkan teknik DInSAR dan data ALOS $P A L S A R$ sebagai data pendukung, maka pada penelitian ini dilakukan pengestimasian besar deformasi di area eksploitasi geothermal akibat eksploitasi fluida geothermal dengan studi kasus area eksploitasi geothermal Lahendong, Sulawesi Utara.

\section{METODOLOGI PENELITIAN}

\section{A. Lokasi Penelitian}

Lokasi penelitian ini mengambil studi kasus wilayah kerja pengusahaan geothermal Lahendong, Provinsi Sulawesi Utara. Posisi Geografisnya terletak pada $1^{0} 13$ ' 12 " - $1^{0} 18$ ' 36 " Lintang Utara dan $124^{0} 48^{\prime} 0^{\prime \prime}$ - $124^{0} 53$ '24" Bujur Timur dengan luas wilayah tercatat $12 \mathrm{~km}^{2}[4]$. 


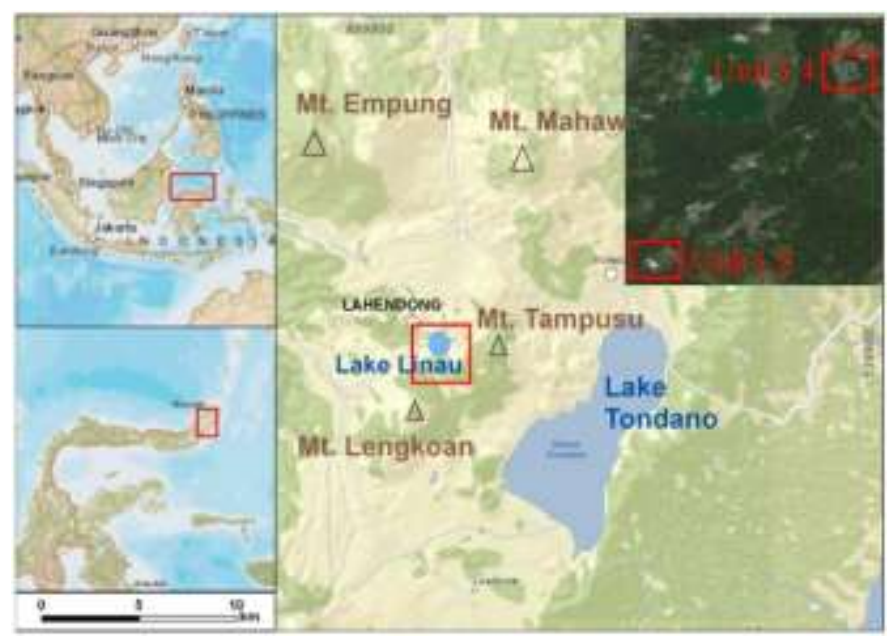

Gambar 1. Peta Topografi Area Lahendong [5

\section{B. Data yang Digunakan}

Penelitian ini menggunakan data citra satelit ALOS PALSAR Level 1.0 dengan Fine Beam Dual Plorazitaion (FBD) pada tanggal 20 Oktober 2007, 22 Oktober 2008, 25 Oktober 2009, dan 29 Oktober 2010. Setelah itu dilakukan proses pembentukan citra interferogram dengan menggabungkan dua buah citra yang dimana salah satu citra disebut citra master dan yang citra lainnya disebut citra slave. Penelitian ini menggunakan data citra tahun 2010 sebagai citra master dan ketiga citra lainnya sebagai citra slave.

Tabel 1.

Spesifikasi Citra ALOS PALSAR yang Digunakan

\begin{tabular}{cccccc}
\hline \hline No & Nama Citra & Perekaman & Orbit & Frame & Arah \\
\hline 1 & ALPSRP & 20 Okt 2007 & 9256 & 10 & Ascending \\
& 092560010 & & & Ascending \\
2 & ALPSRP & 22 Okt 2008 & 14624 & 10 & \\
& 146240010 & & & Ascending \\
3 & ALPSRP & 25 Okt 2009 & 19992 & 10 & \\
& 199920010 & & & & Ascending \\
4 & ALPSRP & 25 Okt 2010 & 25360 & 10 & \\
\hline \hline
\end{tabular}

Selain itu, pada metode DInSAR ini juga diperlukan data DEM yang digunakan untuk proses differential 2-pass interferometry. DEM yang digunakan dalam penelitian ini adalah DEM SRTM 1' yang memiliki ketelitian horizontal $0,00027^{\circ}$, sebanding dengan $\sim 30 \mathrm{~m}$ dan ketelitian vertical dari DEM SRTM 1' ini tidak melebihi 16 m. DEM ini diunduh dari website http://earthexplorer.usgs.gov/.

DEM SRTM 1' digunakan untuk mengurangi phase topografi yang terdapat pada phase interferogram sehingga didapatkan phase deformasi [6]. Dikarenakan resolusi citra $S A R$ dan $D E M$ berbeda, maka phase topografi yang ada tidak seluruhnya hilang. DEM SRTM 1 disimulasikan dengan menggunakan data parameter dari citra master yang terbentuk dari tahap preprocess pengolahan data $S A R$. Tampilan DEM yang digunakan dapat dilihat pada Gambar 3

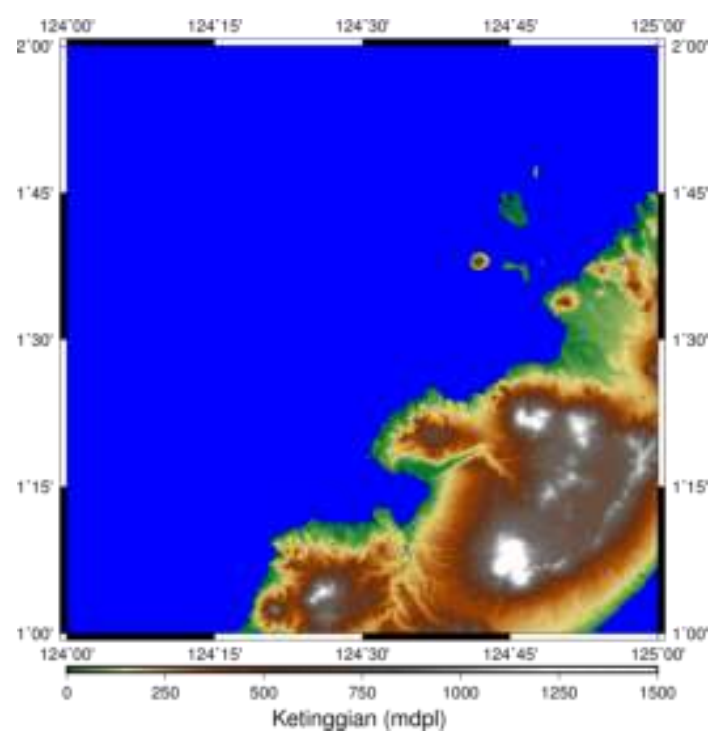

Gambar 2.T ampilan DEMSRTM 1' Sebagian Provinsi Sulawesi Utara

C. Proses Pengolahan Citra dengan GMTSAR

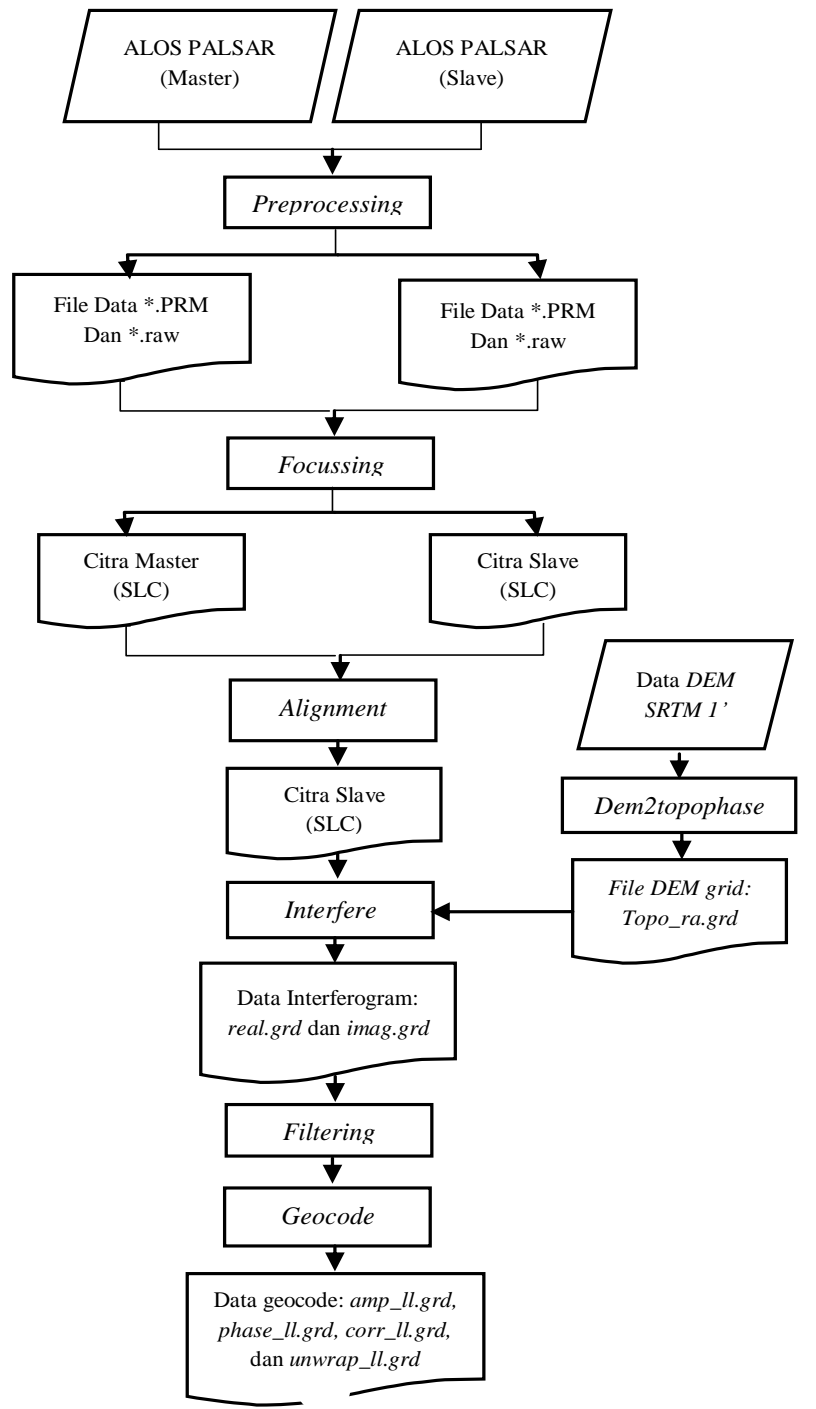

Gambar 3. Diagram Alir Pengolahan Citra dengan GMTSAR 
Penjelasan tahap pengolahan data SAR dengan GMTSAR:

1. Tahap preprocess

Tahap ini dilakukan untuk mendapatkan informasi orbit dan mengetahui parameter ascii file yang berisi parameter untuk InSAR processing dengan mengekstrak orbital satellite dan kecepatannya dari leader file *.LED, image alignment, dan mengestimasi doppler centroid dari data raw yang terdapat pada masing-masing data $S A R$.

2. Tahap focussing dan alignment

Tahap focus dilakukan untuk membuat citra Single Look Complex (SLC) dari masing-masing data SAR. Sedangkan tahap align dilakukan untuk mencari area tampalan dan parameter yang didapatkan dari tahap preprocess oleh citra master terhadap citra slave.

3. Tahap Transformasi Koordinat (DEM2topophase)

DEM yang digunakan adalah DEM SRTM l' yang memiliki sistem koordinat geografis. Pemrosesan yang dilakukan mayoritas dalam sistem koordinat radar, maka harus dilakukan transformasi dari sistem koordinat geografis ke sistem koordinat radar.

Hasil dari tahapan ini ada tiga jenis data, yaitu:

a. Data topo_ra.grd, merupakan koordinat range dan azimuth dalam sistem radar.

b. Postscript image DEM.ps dan topo_ra.ps.

c. Data trans.dat, merupakan koordinat sekutu antara radar dan DEM yakni koordinat range, azimuth dan koordinat geografis

4. Tahap Interfere

Tahap ini dilakukan untuk membuat interferogram dan secara bersamaan mengurangi efek topografi dengan menggunakan DEM yang ada. Tahap interfere dilakukan melalui komen intf.csh. Tahapan tersebut akan menghasilkan dua file yaitu imag.grd dan real.grd yang kemudian dihapus setelah tidak diperlukan lagi.

5. Tahap Filtering

Tahap ini dilakukan untuk menaikkan nilai signal noise ratio (SNR) yang terdapat pada interferogram. Jenis filtering yang digunakan oleh GMTSAR adalah metode Gaussian. Terdapat beberapa jenis filter yang bervariasi dari $100 \mathrm{~m}$ hingga $700 \mathrm{~m}$. Dari tahap pemfilteran ini, diperoleh file interferogram sebelum dan setelah filtering.

6. Tahap Snaphu (Unwrap Processing)

Citra yang dihasilkan dari proses interfere dan filtering masih dalam satuan radian (satuan phase sudut) dalam rentang $-\pi$ sampai dengan $\pi$. Tahap snaphu dilakukan melalui komen snaphu.csh.

7. Tahap Geocode

Tahap geocode dilakukan melalui komen geocode.csh. Dengan kemampuan software GMT, hasil tersebut dapat ditampilkan dalam bentuk phostscript dan $\mathrm{kml}$ Google Earth. Walaupun telah bergeoreferensi, grid, skala, dan informasi lainnya belum ada. Untuk itu, skill menggunakan GMT perlu dilakukan sehingga diperoleh hasil yang artistik akan ditampilkan di bagian hasil.

\section{HASIL DAN ANALISA}

\section{A. Interferogram Phase dan Amplitude}

Citra Single Look Complex (SLC) diolah menjadi interferogram phase dan amplitude dengan tahapan mencari area tampalan (offset) dan komputasi. Akan tetapi, dengan menggunakan perangkat lunak GMTSAR5, citra $S L C$ yang dihasilkan tidak dapat ditampilkan.

Hasil interferogram yang telah dikurangkan dengan efek topografi yang berupa citra phase dan amplitude dalam sistem koordinat radar dapat dilihat pada Gambar 4, 5, dan 6.
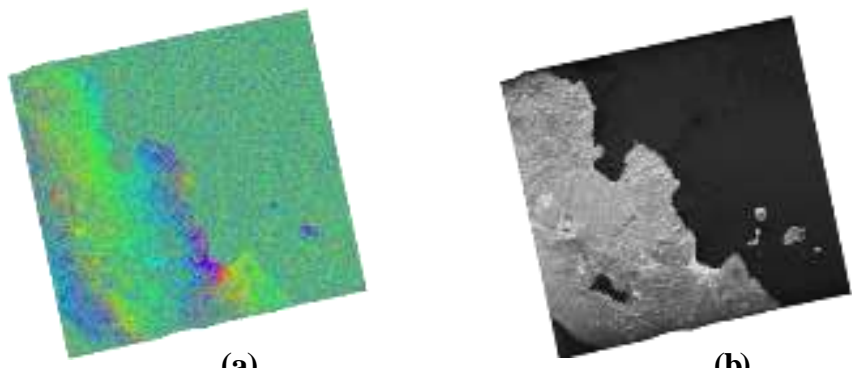

(a)

(b)

Gambar 4. Interferogram Phase Tahun 2007-2010 (a), Interferogram Amplitude Tahun 2007-2010 (b)

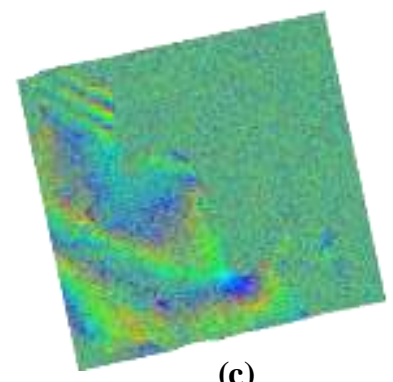

(c)

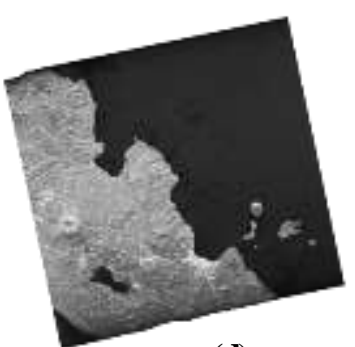

(d)
Gambar 5. Interferogram Phase Tahun 2008-2010 (c), Interferogram Amplitude Tahun 2008-2010 (d)

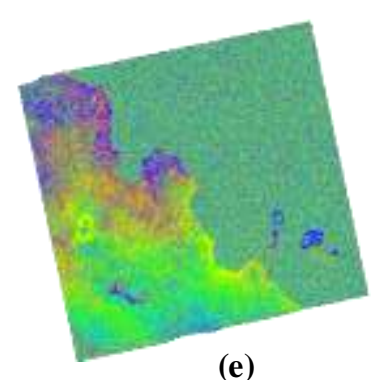

(e)

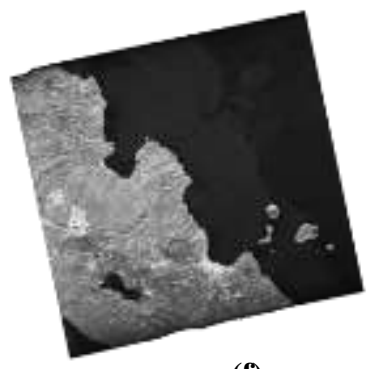

(f)
Gambar 6. Interferogram Phase Tahun 2009-2010 (a), Interferogram Amplitude Tahun 2009-2010 (b)

\section{B. Koherensi Citra}

Untuk melihat tingkat koherensi citra secara kualitatif dapat dilihat dari citra koherensi pada Gambar 7.

Objek daratan pada citra memiliki nilai koherensi rata-rata kurang dari 0,5. Rendahnya nilai koherensi ini karena sebagian besar area studi kasus memiliki kerapatan vegetasi yang tinggi. Kerapatan vegetasi ini akan mempengaruhi nilai koherensi citra karena pergerakan dan perubahan vegetasi akan berpengaruh pada pantulan backscatter-nya. Apabila 
citra koherensi memiliki tingkat koherensi yang tinggi, maka citra akan menunjukan warna yang terang.

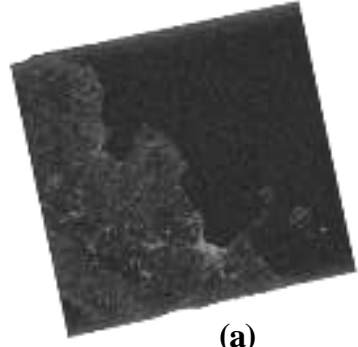

(a)

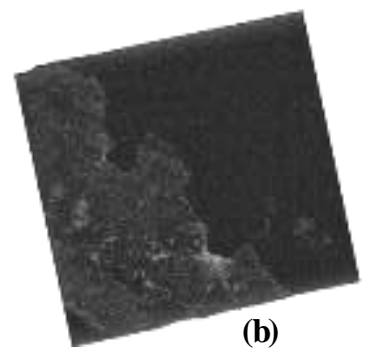

(b)

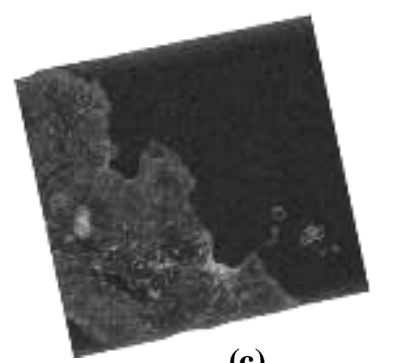

(c)

Gambar 7. Citra Koherensi Tahun 2007-2010 (a), Citra Koherensi Tahun 2008-2010 (b), Citra Koherensi Tahun 2009-2010 (c)

\section{Citra Interferogram Setelah Filtering}

Filtering interferogram ini menggunakan gauss_alos_200m yang merupakan default dari software GMTSAR. Filter ini dipilih karena mampu memberikan hasil yang baik dengan waktu relatif cepat.

Pada Gambar 8, 9, dan 10 adalah hasil interferogram sebelum dan sesudah melalui proses filtering. Pada hasil interferogram sebelum melalui proses filtering, menunjukan adanya noise yang relatif besar pada area yang memiliki tingkat koherensi yang tinggi. Sedangkan interferogram setelah filtering-nya menunjukan peningkatan ketajaman area yang masih memiliki koherensi yang tinggi. (a)

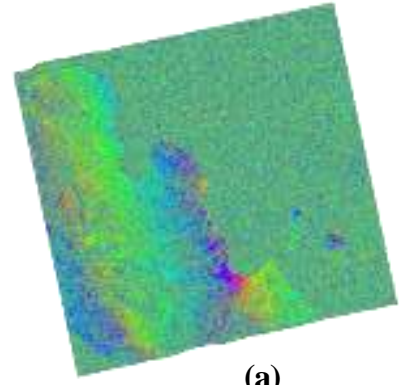

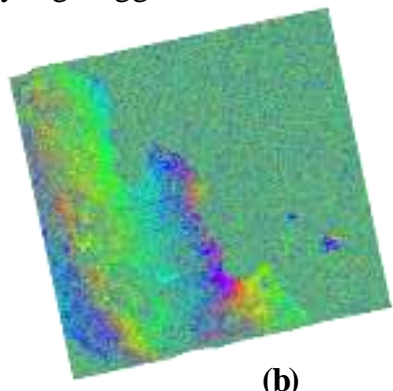

(b)
Gambar 8. Interferogram Phase Sebelum Filtering T ahun 2007-2010 (a), Interferogram Phase Setelah Filtering Tahun 2007-2010 (b)

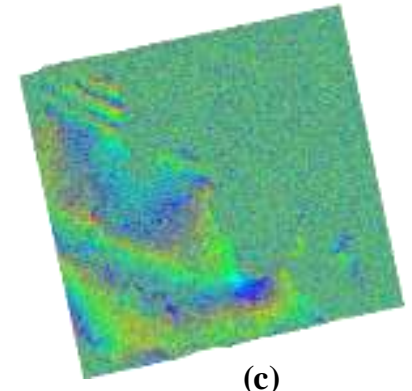

(c)

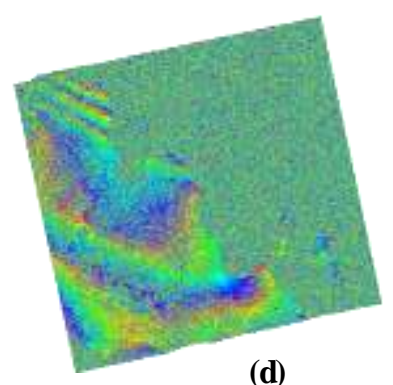

(d)
Gambar 9. Interferogram Phase Sebelum Filtering Tahun 2008-2010 (c), Interferogram Phase Setelah Filtering Tahun 2008-2010 (d)
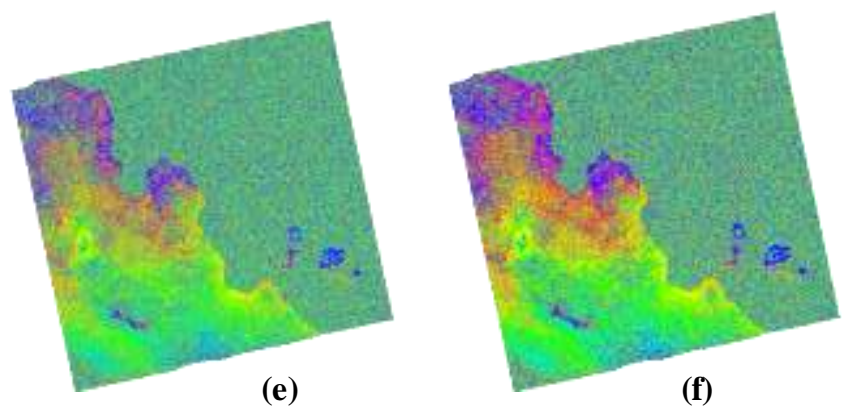

Gambar 10. Interferogram Phase Sebelum Filtering Tahun 2009-2010 (e), Interferogram Phase Setelah Filtering Tahun 2009-2010 (f)

\section{Citra Interferogram Setelah Unwrapping}

Setelah dilakukan unwrapping pada interferogram, maka seperti yang terlihat pada Gambar 11, pola deformasi area sudah dapat diketahui meski masih dalam satuan phase. Untuk mengestimasi besar deformasi dalam satuan metrik, menurut Gabriel (1989) [7] harus dilakukan kalkulasi dengan menggunakan rumus displacement of earth's surface sepanjang sensor Line of Sight (LOS), yaitu:

$$
\Delta \emptyset d e f o=4 \pi \delta \mathrm{R} / \lambda
$$

Dimana $\lambda$ adalah panjang gelombang $S A R$ dan $\Delta \emptyset$ defo adalah nilai perbedaan phase.

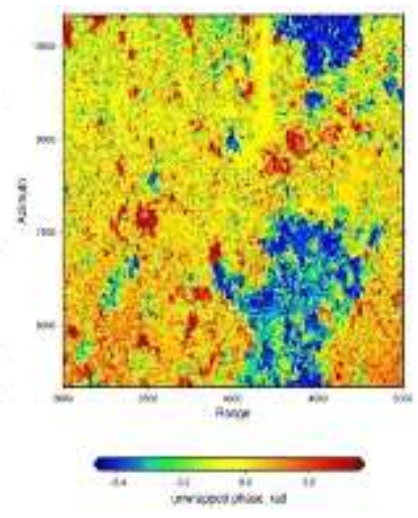

(a)

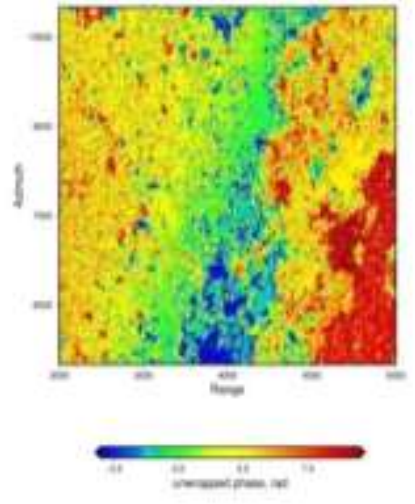

(b)

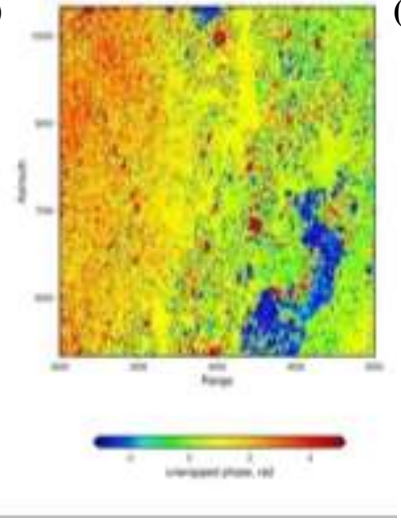

\section{E. Citra Interferogram Setelah Geocode}

Tahap pengolahan terakhir ada(lah melakukan georeference terhadap citra. Hasilnya dapat dilihat gada Gambar 1.2. Tahun 2007-2010 (a), Tahun 2008-2010 (b), dan Tahun 2009-2010 (c) 

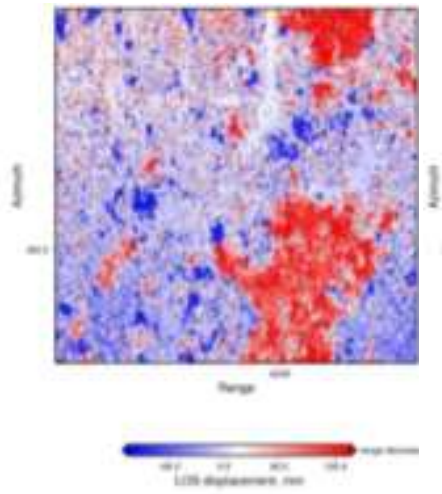

(a)

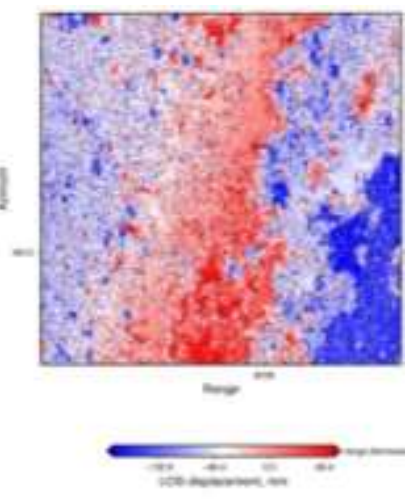

(b)

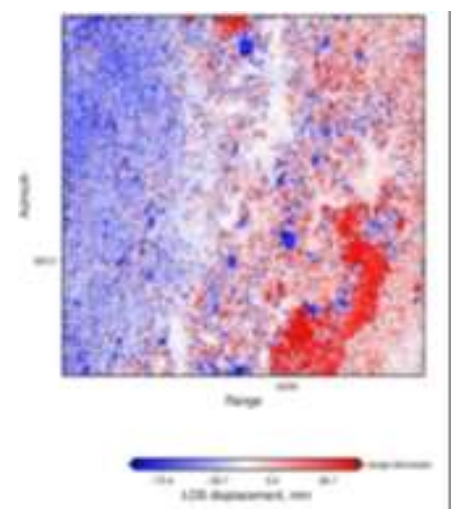

(c)

Gambar 12. Interferogram Phase Citra Setelah Geocoding Tahun 2007-2010 (a), Tahun 2008-2010 (b), dan Tahun 2009-2010 (c)

\section{F. Keakurasian Estimasi Panjang Baseline}

Panjang baseline merupakan faktor terpenting dalam mengukur besar surface deformation dengan InSAR. Menurut Ferreti (2007) [8], untuk mengetahui penyebaran titik orbit dari data pengamatan $S A R$, dapat memilih baseline perpendicular pendek $(\leq 150 \mathrm{~m})$ atau baseline temporal yang pendek. Hal ini juga merupakan faktor didapatkannya nilai koherensi yang tinggi antara citra master dan slave.

Berdasarkan perhitungan pada GMTSAR, estimasi panjang baseline perpendicular data $S A R$ area Lahendong adalah 178,475270 m untuk pasangan citra tahun 2007 dan 2010; 183,664538 m untuk pasangan citra tahun 2008 dan 2010; serta 174,048545 m untuk pasangan citra 2009 dan 2010.

\section{G. Nilai Koherensi}

Telah dijelaskan pada pembahasan sebelumnya bahwa nilai koherensi suatu citra berada antara 0 - 1. Proses interferomety dapat dikatakan baik dan akurat apabila nilai koherensi citranya berada diantara $0,5-1,0$. Apabila nilainya dibawah 0,5, maka hasil citra dari proses interferometry masih memiliki informasi yang berarti, namun citra dengan nilai koherensi tersebut juga menampilkan peningkatan level noise yang sebanding dengan semakin kecilnya nilai koherensi citra. Pada Gambar 13 merupakan grafik nilai koherensi yang menunjukan bahwa besar koherensi dari citra koherensi sangat rendah $(<0,5)$.

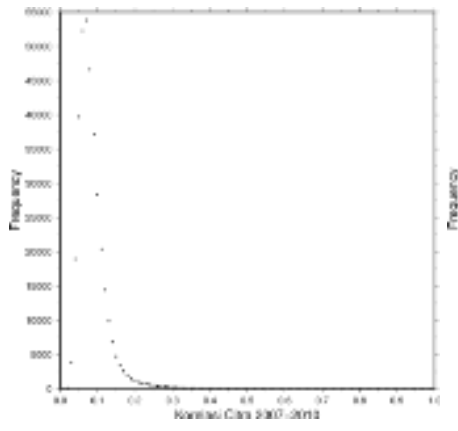

(a)

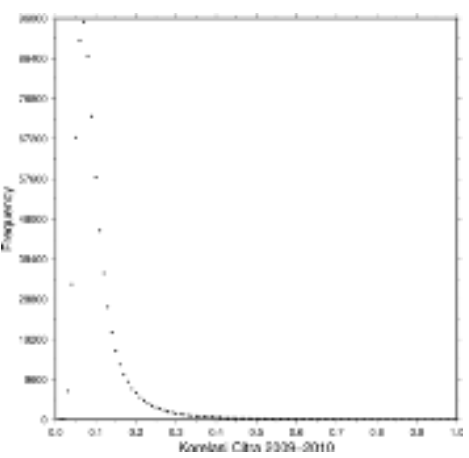

(c)

Gambar 13. Grafik Koherensi Citra Tahun 2007-2010 (a), Tahun 2008-2010 (b), dan Tahun 2009-2010 (c)

Berdasarkan gambar grafik koherensi di atas, dapat disimpulkan hasil plotting besar koherensi citra rata-rata adalah antara 0.05-0.15. Rendahnya nilai koherensi ini menyebabkan banyaknya piksel yang kosong setelah citra melalui proses unwrap.

\section{H. Estimasi Besar Deformasi}

Pada Gambar 14 menunjukkan hasil akhir pengolahan citra dengan metode DInSAR yang dimana telah di-overlay-kan dengan nilai estimasi deformasi pada setiap pikselnya.

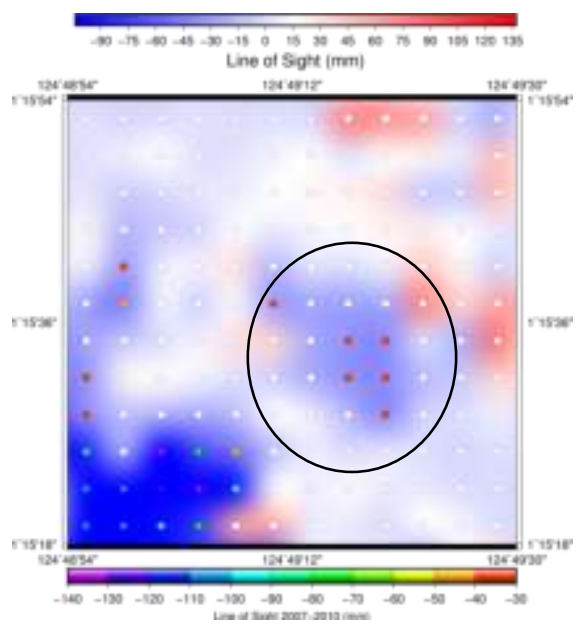

(a) 


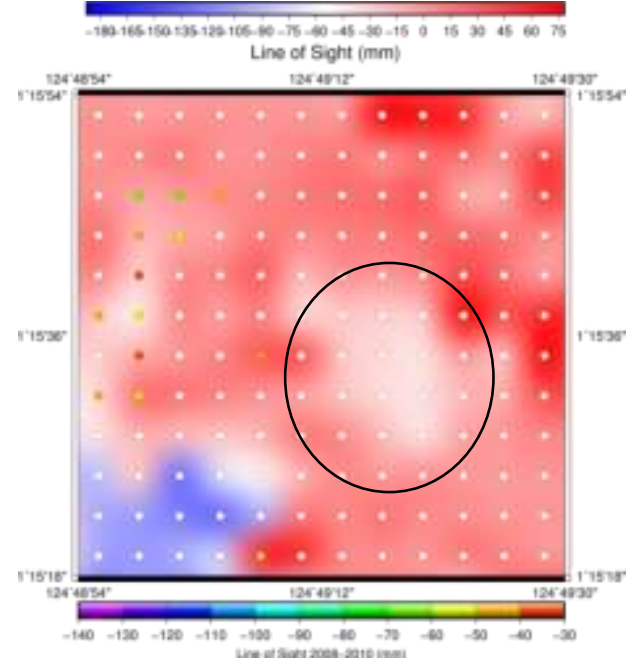

(b)

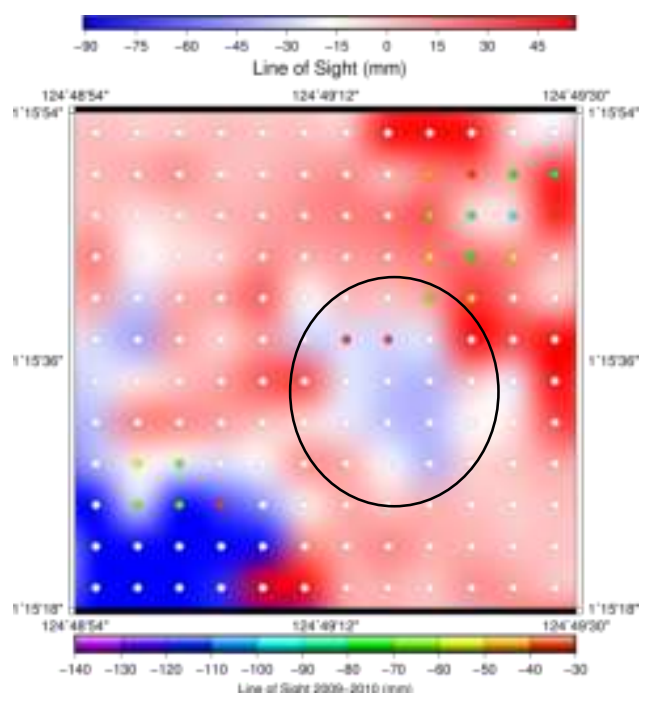

(c)

Gambar 14. Estimasi Besar Deformasi Area PLTPLahendong Tahun 2007-2010 (a), Tahun 2008-2010 (b), dan Tahun 2009-2010 (c)

Kecilnya nilai koherensi menjadi salah satu penyebab banyaknya nilai-nilai piksel yang kosong.

\section{KESIMPULAN DAN SARAN}

Berdasarkan hasil analisa deformasi permukaan tanah akibat eksploitasi panasbumi di PLTP Lahendong, maka didapatkan beberapa kesimpulan, yaitu:

1. Dari hasil pengolahan dengan menggunakan metode DInSAR didapatkan estimasi besar deformasi berdasarkan Line of Sight (LOS) dengan nilai 3 sampai 4 $\mathrm{cm}$.

2. Berdasarkan hasil unwrap pada pengolahan data, menunjukan bahwa proses deformasi sudah terjadi di area eksploitasi panasbumi Lahendong dan itu berupa penurunan muka tanah (land subsidence).

Kemudian berdasarkan hasil pengolahan data dan kesimpulan yang diperoleh, maka penulis memberikan beberapa saran yang dapat diberikan untuk memaksimalkan penelitian selanjutnya adalah sebagai berikut:

1. Untuk mencegah rendahnya nilai koherensi pada citra akibat dekorelasi temporal, maka diperlukan data yang cukup banyak dengan jarak temporal dan baseline yang berdekatan. Untuk jarak temporal dapat dilakukan akuisisi data setiap 6 bulan dengan jarak baseline $\leq 150$ m.

2. Selain tenik DInSAR ini masih memiliki kekurangan berupa dekorelasi temporal, atmosferik, dan noise, maka untuk menambah keakuratan dari hasil pengolahan data, dapat digunakan teknik terbaru dalam pengolahan data SAR yaitu teknik PS-InSAR (Persistent Scattere Interferometry $S A R$ ), seperti yang pernah dilakukan oleh Eneva (2012) [9] yang meneliti deformasi permukaan di Imperial Valley

3. Untuk penelitian selanjutnya dapat diberikan tambahan data pengukuran langsung di lapangan panasbumi Lahendong, berupa data GPS serta melakukan uji validasi untuk mengetahui keakuratan nilai deformasi hasil pengolahan $S A R$ dengan menggunakan teknik DInSAR.

\section{UCAPAN TERIMA KASIH}

Penulis mengucapkan terima kasih kepada Ibu Ira Mutiara Anjasmara yang sudah berkenan memberikan bimbingannya dalam menyelesaikan penelitian ini dan kepada rekan-rekan Laboratorium Geodinamika dan Lingkungan Teknik Geomatika ITS yang sudah memberikan masukan-masukan yang membangun terhadap penelitian ini.

\section{DAFTAR PUSTAKA}

[1] Nenny. 2009. Sekilas Tentang Panas Bumi. Bandung: Institut Teknologi Bandung.

[2] Prabowo, T. 2011. Evaluasi Reservoir Lapangan Geothermal Lahendong-Sulawesi Utara Setelah Berproduksi Selama 10 Tahun. Bandar Lampung, Indonesia: Proceeding of Annual Indonesian Geothermal Association Meeting \& Conference

[3] Japan Space Systems. 2012. PALSARUser's Guide. Japan: Japan Space Systems (J-space systems).

[4] Sardjito. 2013. Pengembangan Panas Bumi Lahendong. $<$ http://www.dunia-energi.com/pge-lanjutkan-pengembangan-panasbumi-lahendong/> dikunjungi tanggal 20 Desember 2015 pukul 11.34

[5] Brehme, M. 2015. The Role of Fault Zone on Structure, Operation and Prospect of Geothermal Reservoirs (Case Study: Lahendong, Indonesia). Göttingen: Georg-August University School of Science.

[6] Hanssen, R. (2001). Radar Interferometry: Data Interpretation and Error Analysis. London: Kluwer Academic Publisher. The Netherlands: Delft University of Technology.

[7] Gabriel, A. G., Goldstein, R. M. \& Zebker, H. A. (1989). Mapping small elevation changes over large areas: Differential radar interferometry. J. Geophys. Res. 94, 9183-9191.

[8] Ferretti, A., Andrea Monti-Guarnieri, Claudio Prati, dan Fabio Rocca. (2007a). InSAR Principles : Guidelines For SAR Interferometry Processing AndInterpretation. The Netherlands: ESA Publications.

[8] Ferretti, A., Andrea Monti-Guarnieri, Claudio Prati, dan Fabio Rocca. (2007b). InSAR Processing : A Practical Approach. The Netherlands: ESA Publications.

[9] Eneva, M.. (2012). Surface Deformation in Imperial Valley, CA, from Satellite Radar Interferometry. Geothermal Resource Council Transaction, Vol. 36. 